\title{
SIMULASI NUMERIK BERBASIS KOMPUTER SEBAGAI SOLUSI PENCEGAH BAHAYA AKIBAT KEGAGALAN BANGUNAN ${ }^{[1]}$
}

\author{
Wiryanto Dewobroto $^{[2]}$, Sahari Besari ${ }^{[3]}$
}

\begin{abstract}
ABSTRAK
Kegagalan bangunan karena strukturnya gagal berfungsi dapat menimbulkan kerugian harta benda, bahkan korban jiwa. Oleh karena itu perlu diantisipasi secara cermat. Bangunan yang didesain terhadap beban-beban rencana dari code-code yang ada, belum dapat menjamin sepenuhnya bebas dari segala risiko kegagalan bangunan, karena penyebabnya kompleks. Salah satu strategi mengantisipasi risiko dapat dimulai dari tahap perencanaan. Langkah pertama yang penting adalah memperkirakan penyebab kegagalan sehingga dapat dibuat simulasi kejadiannya. Selain simulasi fisik (eksperimen) maka simulasi numerik berbasis komputer menjadi alternatif lain yang canggih dan relatif murah. Makalah ini akan membahas seberapa jauh teknologi komputer dapat dipakai sebagai simulasi terjadinya kegagalan bangunan sehingga solusi efektif pencegahannya dapat diupayakan.
\end{abstract}

Kata Kunci : kegagalan bangunan, structural failure, simulasi numerik berbasis komputer.

\begin{abstract}
Building failure due to a malfunction of the structure will impact to the lost of property and even a life. So it is important to make anticipation. Even though buildings have been designed properly according to the design code, but it can not guarantee that building will be free of risk of the failure, because the sources of failure are complex. A strategy to anticipate the failure can be started from the design time. The first important step is a making prediction to the source of failure so that a proper simulation can be done. Beside the physical simulation (experimental), computer base numerical simulation can be used as a sophisticated and an inexpensive alternative. This paper will deal with the computer technology that can be used as simulation of failure in order to predict the weakness part of the structure and make a good solution in preventing the failure.
\end{abstract}

Keywords : building failure, structural failure, computer base numerical simulation.

\section{PENDAHULUAN}

Meskipun sarjana-sarjana di bidang rekayasa teknik sipil sudah banyak di Indonesia, tetapi masih saja dijumpai kegagalan bangunan yang menyebabkan kerugian harta benda atau maupun korban jiwa (KOMPAS Cyber Media). Dengan demikian pembahasan tentang kegagalan bangunan, mengapa, apa dan bagaimana cara mengatasinya masih relevan untuk dibahas.

\section{DEFINISI KEGAGALAN BANGUNAN}

Menyamakan persepsi tentang 'kegagalan bangunan' sangat penting, istilah tersebut dapat berbeda antara satu profesi dengan yang lainnya. Menurut UU No.18/1999 tentang 
JASA KONSTRUKSI, Pasal 1:"Kegagalan bangunan adalah keadaan bangunan, yang $\underline{\text { setelah diserahterimakan oleh penyedia jasa kepada pengguna jasa, menjadi tidak berfungsi }}$ baik sebagian atau secara keseluruhan dan/atau tidak sesuai dengan ketentuan yang tercantum dalam kontrak kerja konstruksi atau pemanfaatannya yang menyimpang sebagai akibat kesalahan penyedia jasa dan/atau pengguna jasa;”. Sedangkan me-nurut Pasal 6: "Bidang usaha jasa konstruksi mencakup pekerjaan arsitektural dan/atau sipil dan/atau mekanikal dan/atau elektrikal dan/atau tata lingkungan, masing-masing beserta kelengkapannya".

Dari definisi di atas tentunya menarik untuk dipertanyakan, bagaimana dengan kasus kegagalan yang terjadi selama pelaksanaan konstruksi, karena hal tersebut sering terjadi dan diberitakan (KOMPAS Cyber Media), misalnya:

1. Ambruknya Ruko di Sunter Akibat Salah Metode Pelaksanaan.

2. Menara Masjid Al Bahar, Koja, Jakarta Utara Ambruk, Empat Tewas.

3. Menara TV 7 di Kebon Jeruk Tumbang, 3 Tewas 15 Rumah Hancur.

Apakah kejadian-kejadian tersebut diluar pembahasan UU No.18/1999 tentang kegagalan bangunan?

Selanjutnya dalam konteks permasalahan ini akan diulas 'kegagalan bangunan' dari sudut pandang pekerjaan sipil. Dalam kaca mata profesi teknik sipil, fungsi utama bangunan adalah memikul beban-beban dan pengaruh lingkungan luar. Jadi bangunan yang gagal adalah jika tidak mampu memikul beban atau rusak akibat pengaruh lingkungan luar. Adapun tolok ukurnya adalah kekuatan dan kekakuan struktur, dan tidak terbatas setelah waktu penyerahan saja tetapi telah dimulai sejak pelaksanaan. Selanjutnya istilah lain yang sepadan adalah 'kegagalan struktur' atau structural failure. Meskipun hanya dipandang dari satu sudut saja tetapi memegang peran yang utama, jika bangunan dari segi kekuatan dan kekakuan tidak berfungsi maka fungsi lainnya pasti juga terganggu. Hanya kegagalan struktur yang berdampak besar terhadap keselamatan jiwa (dan juga kerugian harta benda).

Menurut Ensiklopedia Wikimedia (http://en.wikipedia.org), kegagalan struktur adalah kondisi dimana ada satu atau dua komponen struktur, atau bahkan struktur tersebut secara keseluruhan kehilangan kemampuan menahan beban yang dipikulnya. Umumnya dipicu oleh adanya beban berlebih yang menyebabkan kekuatan (strength) struktur mencapai kondisi batas sehingga menimbulkan fraktur atau lendutan yang besar. Para profesional menyebutnya sebagai keruntuhan struktur. 


\section{PENYEBAB dan MEKANISME KERUNTUHAN yang MUNGKIN TERJADI}

Mengetahui penyebab keruntuhan struktur merupakan langkah awal yang efektif untuk mencegah kejadian tersebut. Dengan mengetahui penyebab keruntuhan struktur, maka dapat dilakukan persiapan yang lebih baik bagi bangunan lain yang sedang direncanakan agar tidak mengalami kejadian yang serupa. Para engineer dapat melakukan evaluasi sejauh mana risiko bahaya yang mungkin terjadi. Bilamana terlalu besar risikonya maka dapat saja bangunan tersebut tidak jadi dibangun.

Menurut Feld dan Carper (1997), struktur bangunan dapat mengalami kerusakan dini (kegagalan) akibat hal-hal berikut :

1. Pemilihan lokasi yang berisiko: daerah yang rawan gempa, banjir atau lereng perbukitan yang tidak stabil terhadap perubahan lingkungan, atau kondisi tanah yang labil atau ekspansif. Meskipun demikian selama risiko tersebut dapat diidentifikasi secara tepat, misalnya dengan dilakukan penyeledikan-penyelidikan khusus (tambah biaya) dan selanjutnya diperhitungkan secara baik pula maka tentunya hal tersebut tidak menjadi masalah.

2. Ketentuan proyek yang tidak jelas: akibat tidak terjadinya komunikasi yang baik antara pemilik dan pelaksana proyek maka dapat terjadi bahwa ekspektasi pemilik ternyata berbeda dengan yang dia harapkan pada awal mulanya, misal ruang terbuka bebas kolom, ternyata akibat kebutuhan struktur harus diberi kolom tambahan dan dalam hal ini pihak arsitek tidak keberatan, tetapi ternyata pihak pemilik selaku penyandang dana berkeberatan dan baru tahu setelah proyek selesai.

3. Kesalahan perencanaan: akibat gambar dan spesifikasi yang tidak lengkap, pemilihan sistem struktur yang rentan kerusakan atau detail yang rawan terhadap kerusakan jangka panjang (misal detail baja yang menangkap air hujan sehingga mudah terjadi korosi), atau karena perencananya sendiri tidak mempunyai kompetensi yang cukup (asal dapat menjalankan program komputer rekayasa dan langsung mengadopsi hasil, meskipun sebenarnya mengandung kesalahan) dsb.

4. Kesalahan pelaksanaan: misal pada penggalian tanah, kecelakaan alat, urutan pelaksanaan atau metode pelaksanaan yang tidak disesuaikan dengan perencanaannya, atau mengganti spesifikasi dengan sengaja untuk mendapatkan keuntungan yang tidak halal.

5. Material yang tidak bermutu: meskipun ada sampel material yang diuji dan telah memenuhi spesifikasi teknis yang ada tetapi dapat saja terjadi cacat yang tidak terdeteksi 
dan baru ketahuan setelah ada kegagalan sehingga tidak bisa dikategorikan kesalahan perencana atau pelaksana.

6. Kesalahan pemakaian: Beban hidup yang tidak sesuai rencana dan fungsinya, misalnya dari hunian menjadi gudang sehingga beban hidupnya berlebihan. Bisa juga akibat kelalaian dalam perawatan, misal lapisan pelindung (cat) pada struktur baja rusak sehingga korosi.

Kecuali hal-hal di atas, akibat perkembangan situasi dunia yang begitu cepat maka perlu ditambahkan juga penyebab baru yang harus diperhitungkan, yaitu beban tak terduga: bencana alam yang sangat jarang terjadi (misal tsunami di Aceh), sabotase, serangan teroris (misal bom Bali, keruntuhan gedung WTC di New York), dsb. Meskipun secara ekonomis tidak layak merencanakan bangunan yang tahan terhadap beban tak terduga tersebut tetapi harus dapat dipastikan bahwa korban akibat kerusakan yang timbul seminimum mungkin.

Mekanisme keruntuhan struktur,

1. Tekuk atau buckling (lokal dan global)

2. Creep (rangkak)

3. Fatig

4. Fraktur, retak

5. Yielding (leleh, deformasi bertambah tanpa ada penambahan beban)

6. Melting (leleh, perubahan dari padat menjadi cair akibat suhu)

7. Korosi

Tiap mekanisme mempunyai perilaku yang berbeda, dan untuk terjadi keruntuhan tidak perlu semua mekanisme tersebut terjadi, jadi cukup satu saja dan terjadilah keruntuhan tersebut. Dari kesemua mekanisme runtuh tersebut, yielding merupakan kondisi dimulainya mekanisme keruntuhan yang sifatnya daktail sehingga diusahakan terjadi terlebih dahulu (jika terpaksa akan terjadi keruntuhan).

\section{SIMULASI NUMERIK BERBASIS KOMPUTER}

\subsection{Pendahuluan}

Dengan mengetahui penyebab dan mekanisme keruntuhan maka selanjutnya dapat dilakukan simulasi pada struktur rencana untuk mengetahui respons yang ditimbulkan, khususnya pada tegangan maupun lendutan yang terjadi. Dari situ dapat dipelajari apakah strukturnya masih mampu berfungsi baik atau telah mengalami keruntuhan, termasuk pula 
bagian mana dari struktur yang paling lemah (komponen struktur yang rusak terlebih dahulu dan yang menjadi sebab keruntuhan secara keseluruhan).

Simulasi dapat dilakukan melalui model fisik maupun model numerik. Model fisik umumnya terbatas pada sampel uji yang relatif kecil sesuai dengan kapasitas alat uji, selain itu biayanya relatif mahal dibanding model numerik. Kalaupun akan dilaksanakan, biasanya dilakukan terlebih dahulu simulasi numerik, sedangkan simulasi fisik adalah terakhir sebagai verifikasi saja.

Akibat perkembangan teknologi komputer yang semakin canggih, baik dari segi hardware maupun software dan harganyapun relatif terjangkau, serta banyak bukti bahwa hasilnya mendekati model fisik (Noor dan McComb 1981) maka simulasi numerik berbasis komputer menjadi pilihan yang banyak dipakai (Willam dan Tanabe 2001, John et.al. 2005, Karim dan Hoo Fatt 2005, Yokihiro et.al. 2005, Wiryanto Dewobroto 2005a/b).

\subsection{Program Komputer untuk Simulasi Keruntuhan}

Analisa struktur dengan metode matriks kekakuan merupakan versi awal metode elemen hingga yang menjadi andalan untuk digunakan bersama dengan komputer. Dasar teori penyelesaian statik yang digunakan metode matriks kekakuan adalah persamaan keseimbangan struktur yang dapat ditulis dalam bentuk matriks sebagai berikut $[K]\{\delta\}=\{F\}$.

Formulasi persamaan keseimbangan memperlihatkan bahwa besarnya deformasi $\{\delta\}$ berbanding lurus dengan gaya $\{\mathrm{F}\}$ yang diberikan, di mana matriks $[\mathrm{K}]$ adalah sesuatu yang menghubungkan perpindahan (deformasi) dan beban. Lebih tepatnya lagi, matriks $[\mathrm{K}]$ adalah besarnya gaya yang diperlukan untuk menghasilkan perpindahan (deformasi) satu satuan.

Kondisi di atas menunjukkan bahwa jenis analisa struktur yang digunakan adalah elastik linier hingga perlu diingat batasan-batasannya sebagai berikut :

1. Lendutan struktur relatif kecil sehingga dapat dianggap kondisi geometri struktur sebelum dan sesudah pembebanan tidak ada perubahan.

2. Material yang digunakan pada struktur masih berperilaku elastis-linier

Kedua kondisi tersebut merupakan prinsip yang dipakai juga untuk analisa struktur klasik untuk mengevaluasi gaya-gaya yang bekerja pada struktur sebagai dasar dalam perencanaan struktur pada umumnya, dan hanya valid jika digunakan untuk mengetahui perilaku struktur pada beban layan.

Sedangkan jika diperlukan simulasi keruntuhan bangunan maka diperlukan analisis yang mampu mencakup daerah in-elastis non-linier, yang sumber penyebabnya pada rekayasa mekanik ada tiga, yaitu : 
a. Geometri non-linier.

b. Material non-linier.

c. Problem kontak, sebagaimana diperlihatkan pada Gambar 1.

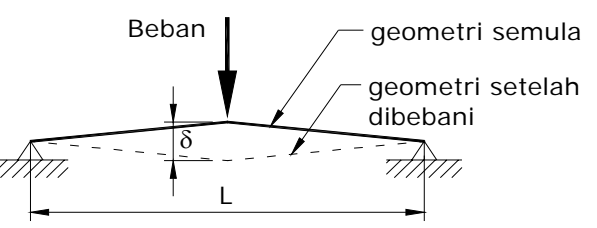

a). Geometri Non-Linier

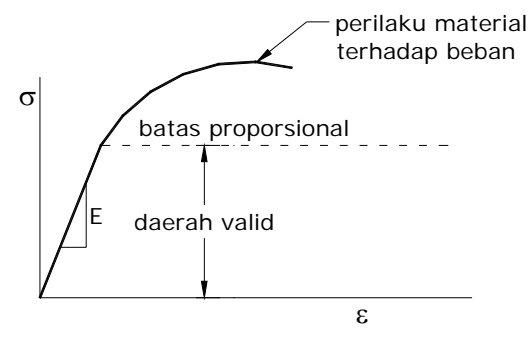

b) Perilaku $\sigma-\varepsilon$ Material yang Non-Linier

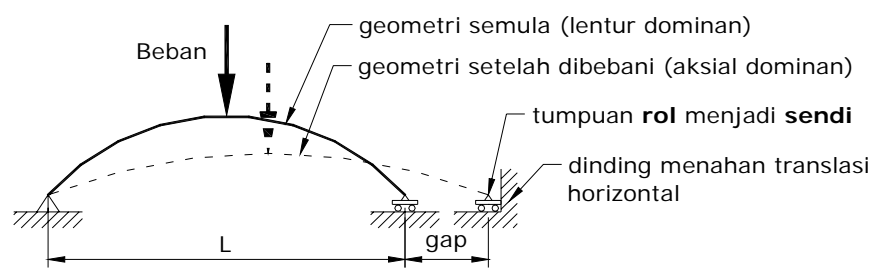

c). Problem Gap atau Kontak

\section{Gambar 1. Non-linier pada Rekayasa Mekanik (Cook et. al. 2002)}

Masalah menjadi non-linier karena kekakuan $[\mathrm{K}]$ dan atau beban $\{\mathrm{F}\}$ merupakan fungsi dari lendutan $\{\delta\}$ atau deformasi. Jika persamaan $[K]\{\delta\}=\{F\}$ bersifat non-linier maka prinsip super-posisi tidak bisa diterapkan. Jadi hasilnya tidak bisa dilakukan proporsional terhadap beban atau super-posisi dengan kasus beban yang lain. Setiap kasus beban yang berbeda memerlukan analisis yang tersendiri, urutan pembebanan juga berpengaruh karena hasilnya bisa berbeda. Solusi persamaan non-linier memerlukan strategi-strategi penyelesaian khusus, karena tiap-tiap strategi penyelesaian hanya cocok untuk kasus-kasus non-linier tertentu, dengan kata lain tidak ada satu strategi ampuh yang dapat menyelesaikan semua persoalan non-linier (general closed form solution).

Kondisi di atas menyebabkan penyelesaian kasus non-linier memerlukan pemahaman yang mendalam dan hati-hati. Adapun hasilnya biasanya bukan merupakan satu angka tunggal tetapi bisa berupa kurva perilaku struktur (kurva gaya-lendutan) terhadap suatu tahapan beban yang diberikan. 


\subsection{Akurasi Simulasi Numerik dengan Realitas (Uji Fisik Laboratorium)}

Simulasi numerik berbasis komputer memakai metode elemen hingga hasilnya semakin lama semakin mendekati hasil real di laboratorium, sehingga biaya yang diperlukan relatif lebih rendah apalagi dapat dengan mudah dilakukan uji parametrik.

Adapun contoh terbaru yang berhasil didapatkan adalah percobaan uji sambungan baja pipa bentuk T di Laboratorium Rekayasa Struktur, NUS (Choo et. al. 2005) dan hasilnya kemudian dibandingkan dengan simulasi numerik berbasis komputer (van der Vegte et. al. 2005) memakai software ABAQUS (http://www.hks.com). Bentuk sambungan baja pipa bentuk $\mathrm{T}$ yang diuji ada beberapa macam dimana masing-masing ada yang diberi perkuatan dan ada yang apa adanya. Gambar 2 memperlihatkan bentuk sampel uji sambungan $\mathrm{T}$ dan model numeriknya.
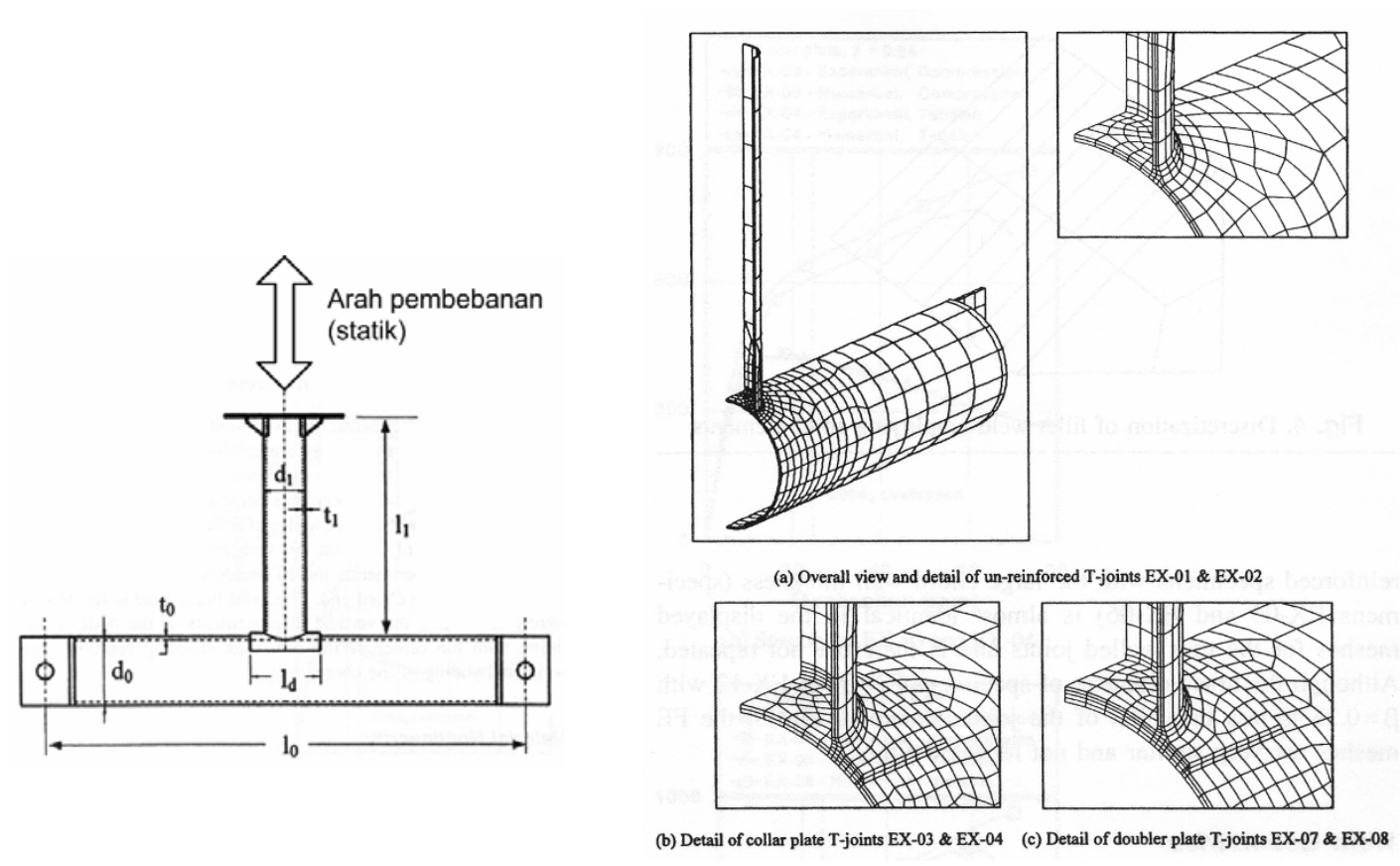

Gambar 2. Bentuk Sambungan Pipa dan Model M.E.H (van der Vegte et. al. 2005)

Perilaku keruntuhan sambungan digambarkan sebagai kurva hubungan bebandeformasi untuk masing-masing tipe sambungan diberikan dalam Gambar 3, dan terlihat bahwa hasil uji real dapat didekati dengan simulasi numerik. Kalaupun ada perbedaan adalah pada daerah putus yang memang sifatnya tiba-tiba. Informasi yang diperoleh tersebut tentunya sudah mencukupi untuk dipakai sebagai data untuk analisis lanjutan untuk struktur yang memakai sambungan tipe tersebut, misalnya untuk analisa push-over (akan dijelaskan lebih lanjut). 
Jika kurva beban-deformasi Gambar 3 menunjukkan perilaku sambungan secara global (menyeluruh) dan umumnya telah mencukupi digunakan sebagai data untuk memprediksi perilaku struktur secara keseluruhan, selain itu dapat juga diperoleh perkiraan deformasi lokal yang terjadi pada sambungan akibat pembebanan tersebut secara detail.

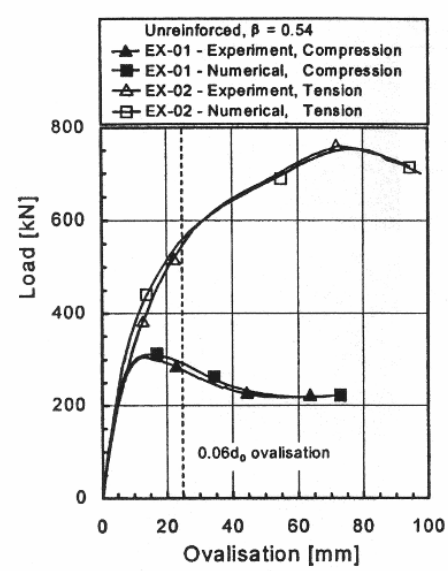

(a) Specimens EX-01 and EX-02

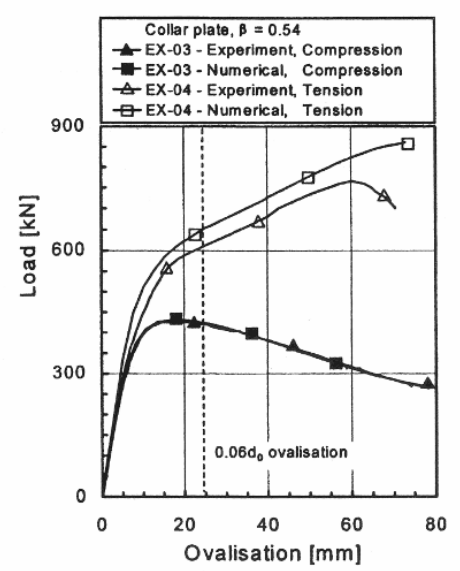

(b) Specimens EX-03 and EX-04

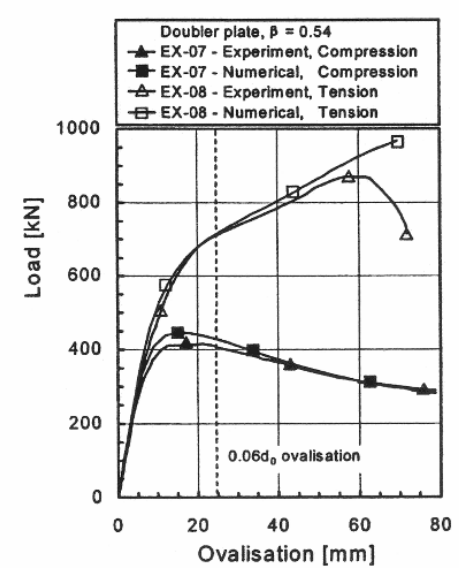

(c) Specimens EX-07 and EX-08

\section{Gambar 3. Perbandingan Hasil Simulasi Numerik dan Real}

(van der Vegte et. al. 2005)

Deformasi lokal pada sambungan tersebut ketika dibandingkan dengan hasil uji fisik ternyata memberi prediksi yang sangat mirip. Informasi visual seperti itu tentu saja sangat membantu memahami perilaku sambungan secara lebih mudah. Selain lebih murah (relatif) jika memakai simulasi numerik maka sampel uji yang diselidiki dapat dengan mudah dimodifikasi (parametrik) dan dibandingkan satu sama lain, dengan demikian dapat diperoleh hasil yang paling optimum, bahkan dapat diketahui detail-detail yang mungkin dapat membahayakan tanpa harus memakainya terlebih dahulu.
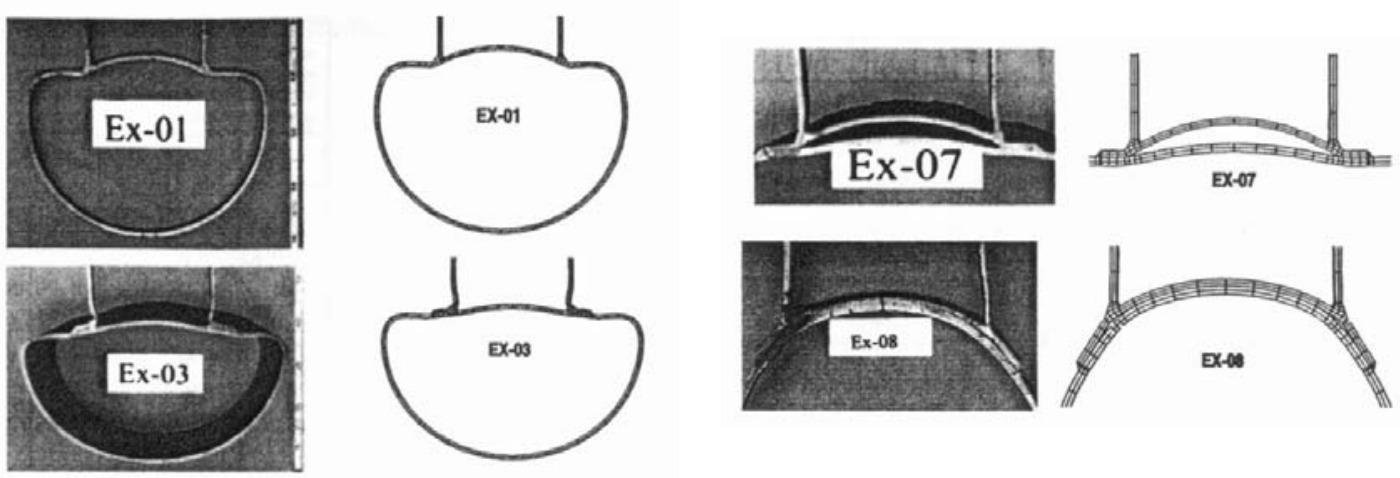

Gambar 4. Perbandingan Deformasi Sambungan Fisik dan Numerik

(van der Vegte et. al. 2005) 
Untuk struktur beton, simulasi numerik dengan 'metode elemen hingga' berhasil dilakukan untuk menyelidiki perilaku keruntuhan balok beton bertulang yang berkategori balok tinggi / deep-beam (Wiryanto Dewobroto 2005b). Seperti diketahui bahwa balok tinggi, yaitu balok dengan $\mathrm{L} / \mathrm{h}<5$ mempunyai perilaku yang berbeda dengan balok biasa sehingga memerlukan perencanaan khusus. Simulasi dilakukan terhadap data balok yang di uji di laboratorium Universitas Toronto (Vecchio-Shim 2004) yang konfigurasinya dapat dilihat pada Gambar 5 .

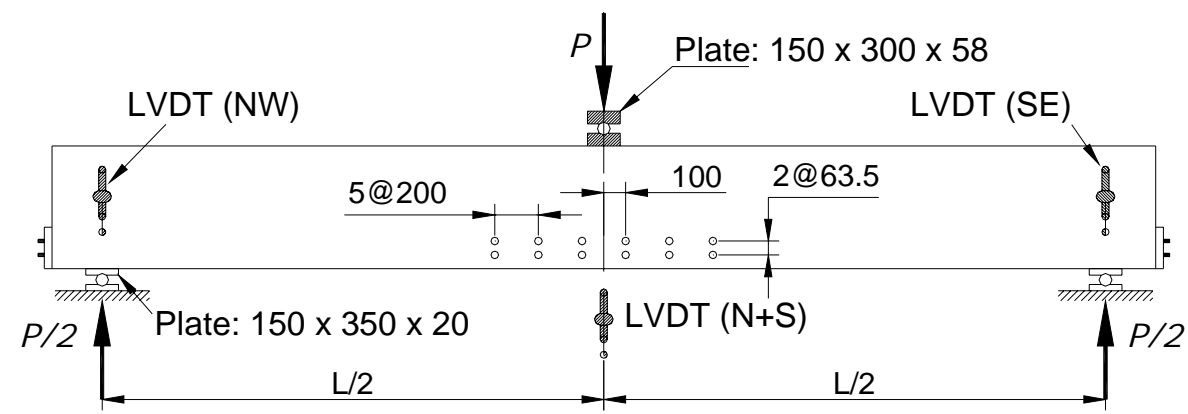

Gambar 5. Setup Balok Uji Universitas Toronto (Vecchio-Shim 2004)

Ada dua balok yang diuji dalam seri OAi dibedakan dalam hal bentangnya dan juga jumlah tulangan yang digunakan, sebagaimana terlihat pada Tabel 1 dan Gambar 6 dan Gambar 7 untuk detailnya.

Tabel 1. Data Dimensi dan Penulangan Balok Bench-mark (Vecchio-Shim 2004)

\begin{tabular}{|c|c|c|c|c|c|c|c|c|}
\hline Kode Balok & $\begin{array}{c}\mathbf{b} \\
\mathbf{( m m )}\end{array}$ & $\begin{array}{c}\mathbf{h} \\
\mathbf{( m m )}\end{array}$ & $\begin{array}{c}\mathbf{d} \\
\mathbf{( m m )}\end{array}$ & $\begin{array}{c}\mathbf{L} \\
\mathbf{( m m )}\end{array}$ & $\begin{array}{c}\text { Span } \\
\mathbf{( m m )}\end{array}$ & $\begin{array}{c}\text { Tulangan } \\
\text { Bawah }\end{array}$ & $\begin{array}{c}\text { Tulangan } \\
\text { Atas }\end{array}$ & Sengkang \\
\hline OA1 & 305 & 552 & 457 & 4100 & 3660 & $2 \mathrm{M} 30,2 \mathrm{M} 25$ & - & - \\
OA2 & 305 & 552 & 457 & 5010 & 4570 & $3 \mathrm{M} 30,2 \mathrm{M} 25$ & - & - \\
\hline
\end{tabular}

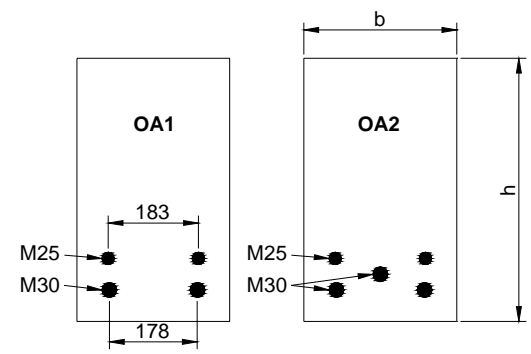

Gambar 6. Detail Balok Bench-mark (Vecchio-Shim 2004) 


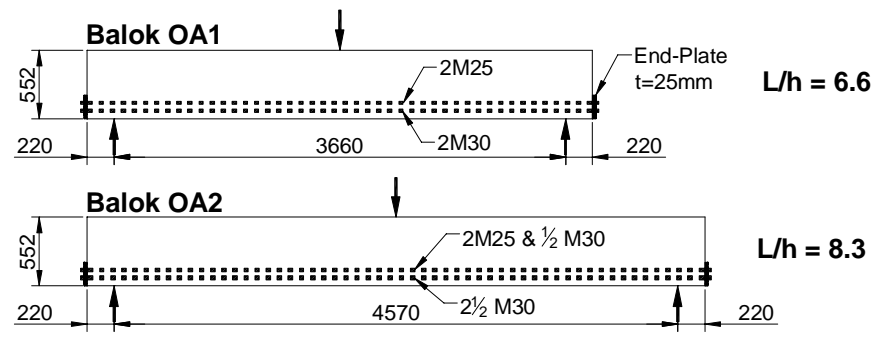

Gambar 7. Elevasi Samping Seri Balok OAi (Vecchio-Shim 2004)

Konfigurasi balok di atas sebenarnya mensimulasi konfigurasi balok yang pernah diuji oleh Bresler-Scordelis (1963) yang merupakan uji eksperimen balok beton bertulang yang hasilnya sering digunakan sebagai rujukan karena cukup lengkap untuk dapat dibandingkan. Simulasi memanfaatkan software ADINA (http://www.adina.com) memakai elemen khusus beton bertulang dalam model 2D, dan hasilnya dibandingkan dengan dua hasil eksperimen tersebut, lihat kurva pada Gambar 8.
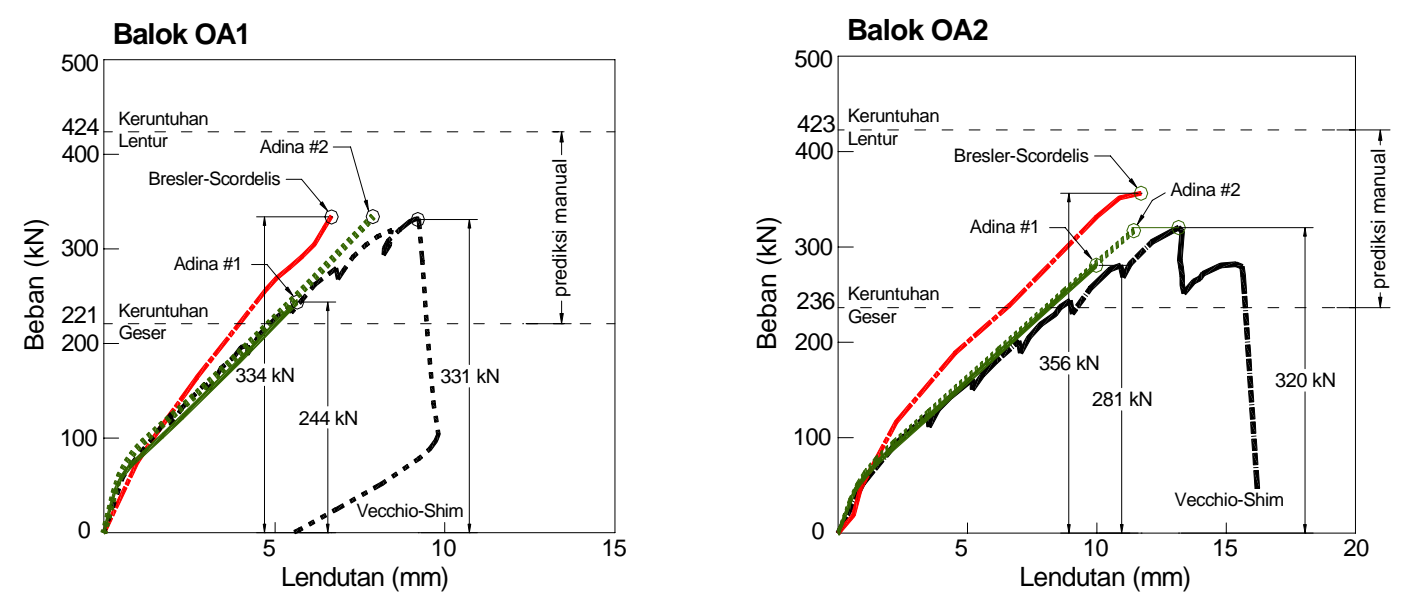

\section{Gambar 8. Perilaku Keruntuhan Balok OA1dan OA2}

(Wiryanto Dewobroto 2005b)

Simulasi numerik dengan ADINA menghasilkan perilaku keruntuhan balok (kurva beban-lendutan) yang terletak diantara kurva-kurva hasil eksperimen (Bresler-Scordelis 1963, Vechio-Shim 2005), artinya simulasi numerik mendekati kondisi real (eksperimen di laboratorium). Jika dibandingkan dengan beban ultimate berdasarkan Code (garis horizontal putus-putus) maka terlihat penyimpangan yang cukup besar. Baik ditinjau sebagai keruntuhan lentur atau akibat keruntuhan geser. 


\subsection{Simulasi Gempa terhadap Bangunan Rencana}

Bangunan pada daerah rawan gempa harus direncanakan mampu bertahan terhadap gempa. Trend perencanaan yang terkini yaitu performance based seismic design, yaitu dilakukan simulasi bangunan terhadap gempa dengan memanfaatkan teknik analisa nonlinier berbasis komputer sehingga dapat dianalisis perilaku inelastis struktur dari berbagai macam intensitas gerakan tanah (gempa), dan dapat diketahui kinerjanya pada kondisi kritis. Dengan demikian dapat dilakukan tindakan bilamana tidak memenuhi persyaratan yang diperlukan. Metode tersebut mulai populer sejak diterbitkannya dokumen Vision 2000 (SEAOC 1995) dan NEHRP (BSSC 1995), yang didefinisikan sebagai strategi dalam perencanaan, pelaksanaan dan perawatan/perkuatan sedemikian agar bangunan mampu berkinerja pada suatu kondisi gempa yang ditetapkan, yang diukur dari besarnya kerusakan dan dampak perbaikan yang diperlukan.

Kriteria kinerja yang ditetapkan Vision 2000 dan NEHRP diperlihatkan pada Tabel 2 berikut :

Tabel 2. Kriteria Kinerja

\begin{tabular}{|c|c|c|}
\hline \multicolumn{2}{|c|}{ Level Kinerja } & \multirow{2}{*}{ Penjelasan } \\
\hline NEHRP & Vision 2000 & \\
\hline Operational & $\begin{array}{c}\text { Fully } \\
\text { Functional }\end{array}$ & $\begin{array}{l}\text { Tak ada kerusakan berarti pada struktur dan non-struktur, } \\
\text { bangunan tetap berfungsi. }\end{array}$ \\
\hline $\begin{array}{l}\text { Immediate } \\
\text { Occupancy }\end{array}$ & Operational & $\begin{array}{l}\text { Tidak ada kerusakan yang berarti pada struktur, dimana kekuatan } \\
\text { dan kekakuannya kira-kira hampir sama dengan kondisi sebelum } \\
\text { gempa. Komponen non-struktur masih berada ditempatnya dan } \\
\text { sebagian besar masih berfungsi jika utilitasnya tersedia. Bangunan } \\
\text { dapat tetap berfungsi dan tidak terganggu dengan masalah } \\
\text { perbaikan. }\end{array}$ \\
\hline Life Safety & Life Safe & $\begin{array}{l}\text { Terjadi kerusakan komponen struktur, kekakuan berkurang, tetapi } \\
\text { masih mempunyai ambang yang cukup terhadap keruntuhan. } \\
\text { Komponen non-struktur masih ada tetapi tidak berfungsi. Dapat } \\
\text { dipakai lagi jika sudah dilakukan perbaikan. }\end{array}$ \\
\hline $\begin{array}{c}\text { Collapse } \\
\text { Prevention }\end{array}$ & $\begin{array}{l}\text { Near } \\
\text { Collapse }\end{array}$ & $\begin{array}{l}\text { Kerusakan yang berarti pada komponen struktur dan non-struktur. } \\
\text { Kekuatan struktur dan kekakuannya berkurang banyak, hampir } \\
\text { runtuh. Kecelakaan akibat kejatuhan material bangunan yang } \\
\text { rusak sangat mungkin terjadi. }\end{array}$ \\
\hline
\end{tabular}

Gambaran mengenai performance based seismic design diperlihatkan pada illustrasi pada Gambar 9. 


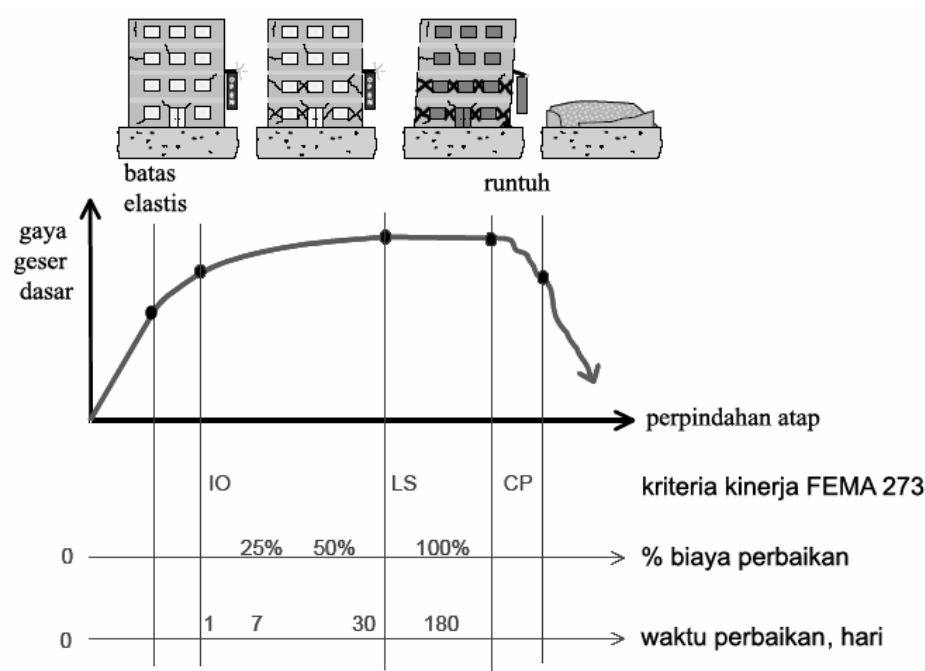

Gambar 9. Illustrasi Rekayasa Gempa Berbasis Kinerja (ATC 58)

Kurva pada Gambar 9 menunjukkan perilaku inelastis bangunan yang diperoleh dari analisa push-over, garis vertikal menunjukkan level-level yang dikalibrasikan dengan tingkat kerusakan yang terjadi (prediksi kerusakan fisik bangunan). Selanjutnya ditentukan target perpindahan $\delta_{\mathrm{t}}$. yang ditentukan oleh macam gempa yang disimulasikan sehingga diketahui tingkat kerusakan yang terjadi (lihat Tabel 4.1).

Untuk melihat contoh implementasi perencanaan berbasis kinerja pada bangunan baja 6 lantai dengan konfigurasi lantai yang regular dan tipikal maka diperlihatkan hasil analisa push-over memakai SAP2000 (Wiryanto Dewobroto 2004) dan diperlihatkan kondisi bangunan setelah tahapan ke-5 dalam pemberian beban dorong lateral, maupun kondisi inelastis yang terjadi (Wiryanto Dewobroto 2005a).

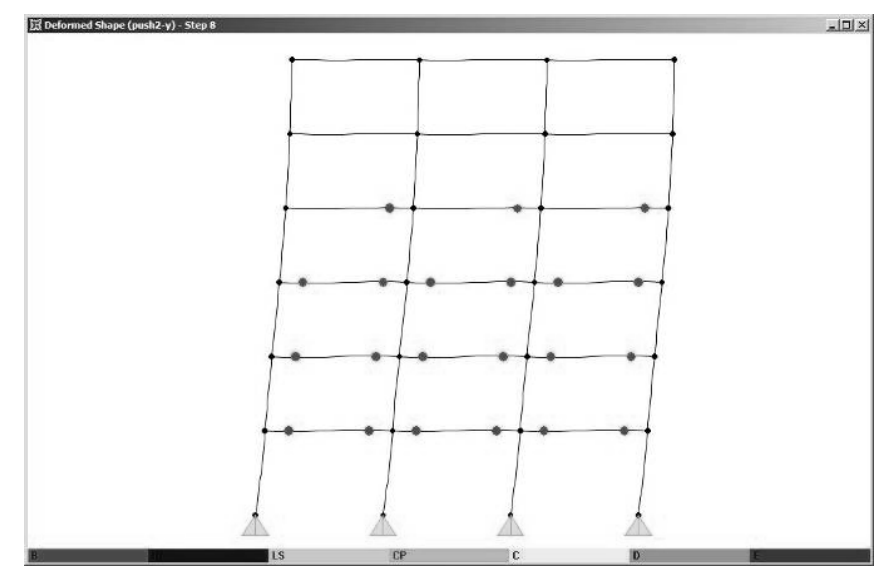

Gambar 10. Kinerja Struktur Arah Sisi Pendek pada Step - 5 (Wiryanto Dewobroto 2005a) 


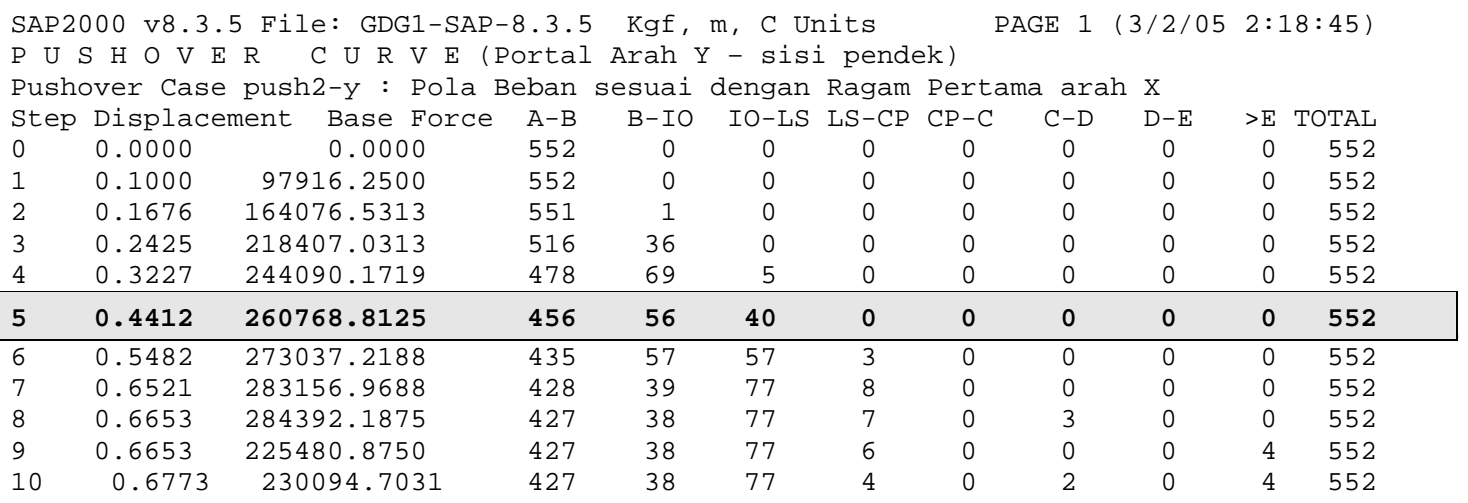

Note: step adalah tahapan pemberian beban lateral dan tahap terbentuknya sendi plastik pada portal.

Simulasi gempa dengan analisa push-over pun tidak serta merta mampu memprediksi semua keruntuhan yang mungkin terjadi, keruntuhan yang dimaksud hanya tipe keruntuhan tertentu yang telah diprediksi terlebih dahulu seperti misalnya terjadinya sendi plastis pada elemen struktur. Tentu saja itu dapat terjadi jika elemen struktur yang digunakan telah memenuhi persyaratan-persyaratan tertentu. Bahkan untuk mendapatkan akurasi dari analisis, diperlukan verifikasi model bagian elemen yang diharapkan terjadi sendi plastis dengan hasil eksperimen di laboratorium.

Meskipun prediksi dengan analisa push-over dapat saja tidak tepat, tetapi ini merupakan suatu cara yang paling mendekati dalam memperkirakan besarnya kerusakan yang timbul terhadap gempa tertentu dan telah menjadi trend perencanaan bangunan tinggi pada saat ini (Budiono et. al. 2004).

\subsection{Simulasi terhadap Beban Tak Terduga - Kasus Tabrakan BOEING ke gedung WTC.}

Sesuai dengan namanya yaitu beban tak terduga maka keberadaannya baru diketahui jika telah terjadi. Kalaupun dapat diperkirakan sebelumnya, umumnya hanya berupa wacana dan biasanya tidak diaplikasikan dalam perencanaan sebenarnya karena mengandung konsekuensi pada biaya. Kalau sudah terjadi maka perencana tentu mau tidak mau perlu untuk mempertimbangkan keberadaannya.

Pada prinsipnya selama dapat diketahui secara detail beban tak terduga tersebut maka dapat dilakukan simulasi untuk melihat pengaruhnya pada bangunan yang direncanakan untuk mengetahui dampak yang ditimbulkannya. Sebagai gambaran diperlihatkan dua hasil simulasi pada beban tak terduga berupa tabrakan pesawat BOEING pada gedung WTC New York. Siapa yang akan mengira bahwa ke dua gedung tinggi 
tersebut akan ditabrak oleh dua pesawat besar sekaligus, sehingga tidak bisa disalahkan bila bangunan tersebut roboh karena tidak kuat menghadapi peristiwa tak terduga tersebut.

Simulasi Karim dan Hoo Fatt (2005) memakai metoda elemen hingga dengan software LS-DYNA3D menunjukkan bahwa bilamana kolom pada gedung WTC tersebut mempunyai ketebalan baja $>20 \mathrm{~mm}$ maka sayap pesawat tidak akan mampu mengoyak kolom luar bangunan (Gambar 11). Adapun ketebalan baja $9.5 \mathrm{~mm}$ pada kolom yang ada, berdasarkan simulasi yang dilakukan, terlihat bahwa sayap pesawat dapat memotong kolom luar sehingga badan pesawat dan tangki bahan bakar dapat masuk dan terbakar didalam gedung. Dari penyelidikan yang dilakukan dinyatakan bahwa kerusakan parah adalah akibat adanya kebakaran pada gedung WTC yang mengakibatkan baja strukturnya melemah, dan terjadilah keruntuhan fatal yang menewaskan ribuan orang tersebut.

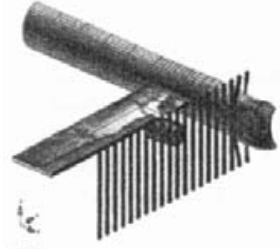

(a)

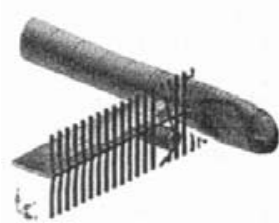

(c)

A. Tebal plat kolom $=9.5 \mathrm{~mm}$, keadaan pada kecepatan (a) $\mathrm{t}=25 \mathrm{~ms}$, (b) $\mathrm{t}=40 \mathrm{~ms}$, (c) $\mathrm{t}=56 \mathrm{~ms}$ dan (d) $\mathrm{t}=73 \mathrm{~ms}$

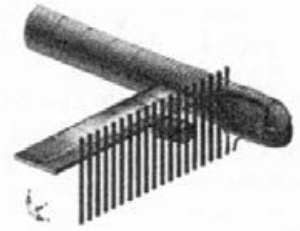

(b)

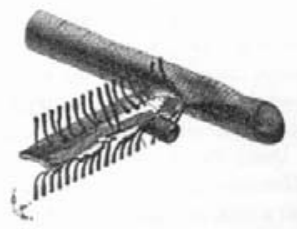$$
\text { (c) }
$$

$$
\text { (i) }
$$

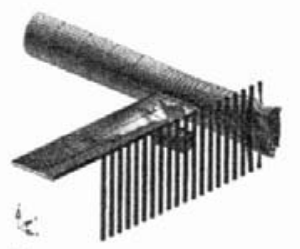

(a)

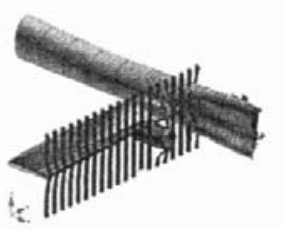

(c)

B. Tebal plat kolom $=20 \mathrm{~mm}$, keadaan pada kecepatan (a) $\mathrm{t}=25 \mathrm{~ms}$, (b) $\mathrm{t}=40 \mathrm{~ms}$, (c) $\mathrm{t}=56 \mathrm{~ms}$ dan (d) $\mathrm{t}=75 \mathrm{~ms}$

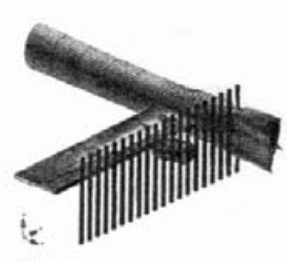

(b)

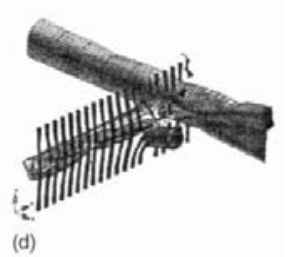

(c)

\section{Gambar 11. Simulasi Penetrasi Kolom Perimeter WTC dengan Pesawat BOEING (Karim dan Hoo Fatt 2005)}
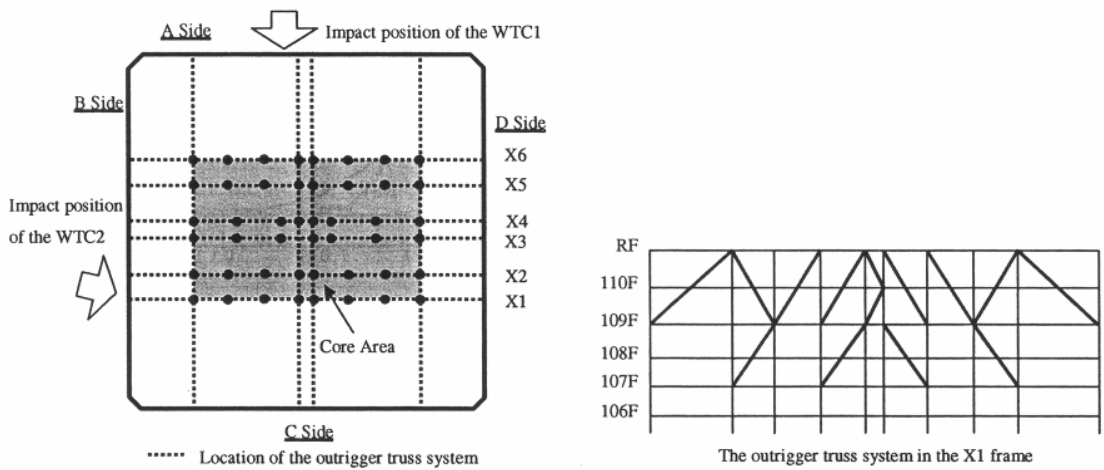

Gambar 12. Sistem Outrigger dan penempatannya (Yokihiro et. al. 2005) 

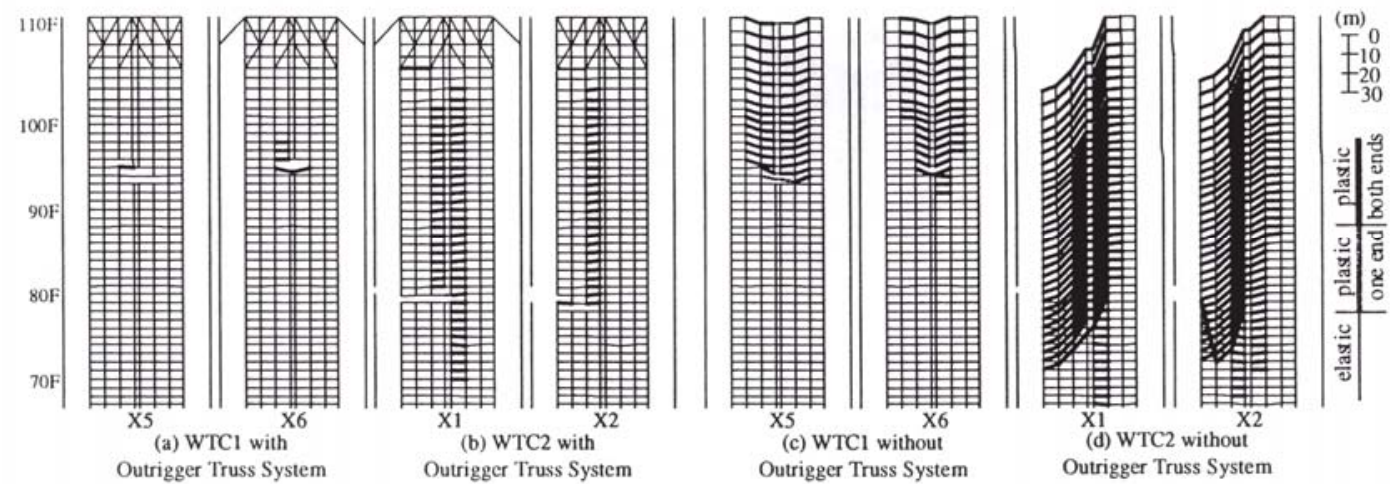

Gambar 13. Pengaruh Sistem Struktur pada Keruntuhan WTC

(Yokihiro et. al. 2005)

Simulasi pada Gambar 11 sifatnya lokal/setempat untuk mengetahui kekuatan kolom perimeter terhadap efek penetrasi badan pesawat yang menabrak. Peneliti lain (Yokihiro et. al. 2005) juga melakukan simulasi memakai program LS-DYNA juga untuk melihat pengaruh tabrakan terhadap struktur keseluruhan. Dari simulasi yang dilakukan diperoleh informasi bahwa jika gedung WTC memakai suatu sabuk struktur yang disebut sistem Outrigger yang ditempatkan pada bagian puncak maka gedung tersebut tidak mengalami keruntuhan yang fatal seperti yang telah terjadi.

Dari simulasi yang dilakukan diyakini bila gedung WTC memakai sistem Outrigger maka tabrakan pada bagian tengah yang menyebabkan kerusakan lokal tidak menyebabkan kolom di atasnya jatuh kebawah karena dapat ditahan oleh sistem tersebut dan selanjutnya mendistribusikan ke bagian struktur yang lain seperti yang terlihat pada Gambar 13.

Pada saat perencanaan gedung WTC memang tidak didesain untuk mendapat beban tumbuk dari suatu pesawat sebesar BOEING karena umumnya hanya didesain terhadap beban horizontal akibat angin atau gempa yang memang umum terjadi. Jika dari semula sudah diperkirakan ada beban sebesar tersebut maka kiranya dapat dirancang suatu bangunan yang mampu bertahan terhadap kondisi tersebut. Jadi masalahnya adalah ketidak-tahuan bahwa beban sebesar itu memang akan terjadi.

\section{PEMBAHASAN}

Contoh yang disajikan dalam makalah ini hanya sebagian kecil dari makalahmakalah yang ada tentang simulasi keruntuhan struktur cara numerik berbasis komputer. Karena dipilih dari jurnal struktur yang kompeten dan terbaru maka merupakan state of the art tentang masalah tersebut . 
Program komputer yang dapat digunakan untuk simulasi sudah cukup banyak tersedia. Adapun software yang dibahas adalah ABAQUS, ADINA, LS-DYNA dan SAP2000, sedangkan yang lainnya dapat dengan mudah di cari di internet, misalnya DIANA, ANSYS, NASTRAN, dan sebagainya.

Meskipun tool analisis sudah ada tetapi simulasi keruntuhan cara numerik berbasis komputer tidak serta merta menjadi sesuatu yang mudah. Hal-hal yang menjadi kendala sehingga membutuhkan s.d.m yang berkompeten untuk melakukannya adalah:

1. Skenario keruntuhan yang dianalisis harus diidentifikasi terlebih dahulu, meskipun demikian tidak ada jaminan bahwa skenario tersebut memang benar yang menjadi penyebab keruntuhan. Untuk itulah fungsi forensik engineer diperlukan, sampai akhirnya dapat ditentukan skenario sebenarnya sehingga dapat dilanjutkan siapa yang harus bertanggung jawab dengan kejadian tersebut.

2. Perlu disusun model matematik terlebih dahulu, dan agar berguna model harus mewakili kondisi real. Tahapan tersebut belum dapat secara otomatis dikerjakan komputer tetapi hanya dapat dibuat oleh engineer yang berkompeten. Selain itu model harus disesuaikan dengan kemampuan software komputer yang digunakan. Karena masalah non-linier relatif cukup kompleks sehingga tidak tiap program mempunyai option yang sama dalam menyelesaikannya.

3. Output simulasi numerik umumnya berupa kurva-kurva beban-lendutan dan sebagainya, dan berbeda dengan analisa struktur cara eleastik linier yang menyajikan suatu nilai tertentu.

\section{KESIMPULAN}

Telah tersedia tool-tool canggih untuk mempelajari perilaku struktur terhadap beban dari awal sampai keruntuhannya, sehingga dengan mempelajari mekanisme keruntuhan dapat dipilih langkah-langkah yang dapat mencegah bahaya yang timbul bilamana keruntuhan terjadi.

Masalah mengenai hal-hal (beban) tak terduga yang mengakibatkan kegagalan bangunan masih di luar kemampuan perencana. Dalam hal ini, peran serta media massa dalam menyebarluaskan info adanya kegagalan bangunan dan faktor-faktor penyebabnya menjadi acuan yang cukup penting. 


\section{DAFTAR PUSTAKA}

1. Budiono, B., Rosalina, A., Sukamta, D. dan Mettawana, S. (2004), Analisa PUSHOVER pada Gedung 48 Lantai THE PEAK, Seminar dan Pameran HAKI 2004: Excellence in Construction, Hotel Borobudur, 24-25 Agustus 2004.

2. BSSC. (1995), FEMA 222 - NEHRP Recommended Provision for Seismic Regulations for New Building, Washington, D.C.

3. Bresler. B, dan Scordelis A.C. (1963), Shear strength of reinforced concrete beam, J. Am. Concr. Inst., 60(1), 51-72.

4. Choo, Y.S., van der Vegte, G.J., Zettlemoyer, N., Li, B.H. dan Liew, J.Y.R. (2005), Static Strength of T-Joints Reinforced with Doubler or Collar Plates. I: Experimental Investigations, J. Struct. Eng., 131(1) , 119 - 128

5. Cook, R.D., Malkus, D.S., Plesha, M.E. dan Witt, R.J. (2002), Concept and Applications of Finite Element Analysis $4^{\text {th }}$ Ed., John Wiley \& Sons, Inc.

6. Feld, J. dan Carper K. (1997), Construction Failure $2^{\text {nd }}$ Ed., John Wiley \& Sons, Inc., New York, dikutip dari Construction \& Equipment Spotlight : Why do some structures fall down?, < http://www.djc.com/special/const97/10023875.html >, akses $2 / 3 / 2006$

7. KOMPAS Cyber Media :

a. "Gempa di Iran Tewaskan Sedikitnya 2000 Orang - 26/12/2003", $<$ http://kompas.com/utama/news/0312/26/193709.htm >

b. "Ambruknya Ruko di Sunter Akibat Salah Metode Pelaksanaan - 03/06/2004", $<$ http://kompas.com/metro/news/0406/03/111909.htm >

c. "Kelebihan Beban, Jembatan Cipunagara Ambruk - 24/07/2004", < http://kompas.com/utama/news/0407/24/232500.htm >

d. "Korban Hotel Ambruk, Dua Tewas dan 15 Luka - 04/08/2004", < http://kompas.com/utama/news/0408/04/222251.htm >

e. "Masjid Ambruk, Empat Tewas - 22/12/2005", < http://kompas.com/metro/news/0512/22/090734.htm >

f. "Menara TV 7 Tumbang, Tiga Orang Tewas 15 Rumah Hancur - 23/01/2006", < http://kompas.com/metro/news/0601/23/234312.htm >

g. "Papan Reklame Tumbang, Jalan Gelora Macet - 23/01/2006", < http://kompas.com/metro/news/0601/23/172719.htm >

h. "Atap Balai Pameran Runtuh - Senin, 30 Januari 2006", $<$ http://kompas.com/kompas-cetak/0601/30/ln/2402274.htm > 
8. Karim, M.R. dan Hoo Fatt, M.S. (2005), Impact of the Boeing 767 Aircraft into the World Trade Center, J. Eng. Mech, 131(10), 1066-1072.

9. Noor, A.K. and H.G.McComb, Ir. (1981), Computational methods in NONLINEAR STRUCTURAL and SOLID MECHANICS, Papers presented at the Symposium on Computational Methods in Nonlinear Structural and Solid Mechanics - Held 6-8 October 1980, Washington DC, Pergamon Press Ltd.

10. SEAOC. (1995), Vision 2000 - A Framework for Performance Based Earthquake Engineering, Vol. 1, January, 1995.

11. Yukihiro Omika; Eiji Fukuzawa; Norihide Koshika; Hiroshi Morikawa dan Ryusuke Fukuda. (2005), Structural Responses of World Trade Center under Aircraft Attacks, J. Struct. Eng., 131(1), 6-15

12. Van der Vegte, G.J., Choo, Y.S., Liang, J.X, Zettlemoyer, N. dan Liew, J.Y.R. (2005), Static Strength of T-Joints Reinforced with Doubler or Collar Plates. II: Numerical Simulations, J. Struct. Eng., 131(1) , 129 - 138

13. Vecchio, F.J. dan Shim, W. (2004), Experimental and Analytical Re-examination of Classic Concrete Beam Tests, J. Struct. Eng., 130(3), 460 - 469

14. Dewobroto, W. (2004), Aplikasi Rekayasa Konstruksi dengan SAP2000, PT. Elex Media Komputindo, Jakarta

15. Dewobroto, W. (2005a), Evaluasi Kinerja Struktur Baja Tahan Gempa dengan Analisa Pushover, Presentasi dan Prosiding: Civil Engineering National Conference "Sustainability Construction \& Structural Engineering Based on Professionalism", Unika Soegijapranata, Semarang, 17-18 Juni 05.

16. Dewobroto, W. (2005b), Simulasi Keruntuhan Balok Beton Bertulang Tanpa Sengkang dengan ADINA, Prosiding Seminar Nasional "Rekayasa Material dan Konstruksi Beton 2005”, Jurusan Teknik Sipil ITENAS, 4 Juni 05 , Hotel Grand Aquilla, Bandung.

[1] Disampaikan dalam Seminar "Kegagalan Bangunan, Solusi dan Pencegahan", Universitas Pelita Harapan, 3 Mei 2006.

[2] Wiryanto Dewobroto, Dosen Tetap Jurusan Teknik Sipil Universitas Pelita Harapan, Kandidat Doktor UNPAR.

[3] Sahari Besari, Profesor Emeritus, ITB, Promotor pada Program Doktor Teknik Sipil UNPAR. 